\title{
Remote Sensing and Economic Indicators for Supporting Water Resources Management Decisions
}

\author{
Petra J. G. J. Hellegers • Richard Soppe • \\ Chris J. Perry • Wim G. M. Bastiaanssen
}

Received: 11 June 2009 / Accepted: 9 December 2009 /

Published online: 24 December 2009

(C) The Author(s) 2009. This article is published with open access at Springerlink.com

\begin{abstract}
This paper demonstrates that combining spatial land surface data with socio-economic analysis provides a number of indicators to strengthen decision making in integrated water and environmental management. It provides a basis to: track current water consumption in the Inkomati Basin in South-Africa; adjust irrigation water management; select crop types; facilitate planning; estimate crop yields before harvesting, and consequently to forecast market price development. Remote sensing data and economic analysis can also be used to study the spatial distribution of water consumption as an indicator of equity in access to water resources. It even enables identification of farms that consume more irrigation water than formally allocated. Finally, it provides a basis to assess the cost-effectiveness of various ways to reduce agricultural water consumption. So, this approach is potentially useful for determining water consumption, refining water allocation policies, and determining the potential for water transfers through mechanisms such as water trading.
\end{abstract}

Keywords Remote sensing $\cdot$ Economic analysis $\cdot$ Cost-effectiveness $\cdot$ Spatial and temporal variability $\cdot$ Water consumption $\cdot$ Excess use $\cdot$ Opportunity costs

This paper is written in the framework of 'A demonstration project in the Inkomati Basin' (Soppe et al. 2006) funded by the 'Partners for Water II' program of the Dutch government.

P. J. G. J. Hellegers $(\varangle)$

LEI-Wageningen UR, P.O. Box 29703, 2502 LS The Hague, The Netherlands

e-mail: petra.hellegers@wur.nl

R. Soppe · W. G. M. Bastiaanssen

WaterWatch, Generaal Foulkesweg 28, 6703 BS Wageningen, The Netherlands

C. J. Perry

Independent Consultant, 17 Storey Court, London NW8 8QX, UK

W. G. M. Bastiaanssen

Delft University of Technology, Stevinweg 1, 2600 GA Delft, The Netherlands 


\section{Introduction}

In this paper an innovative method combining technical and socio-economic analysis is applied to the Inkomati Basin in the eastern part of South Africa. A detailed description of this method has recently been published (Soppe et al. 2006; Hellegers et al. 2009), but the pratical applicability has so far only been shown to a limited extent. To date, only the spatial variability in both bio-physical crop water productivity (CWP) and economic water productivity (EWP) of existing land use has been shown, which allows assessment of the size of potential gains and losses of spatial water reallocations. Before demonstrating the usefulness of the combined method to assess a set of other indicators, the basics of the method are first summarized.

The Surface Energy Balance Algorithm for Land (SEBAL) (Bastiaanssen et al. $2002,2005)$ has been in use for 20 years. The model uses remote sensing data and the physics of the energy balance to estimates actual and potential evapotranspiration $\left(\mathrm{ET}_{\mathrm{act}} ; \mathrm{ET}_{\mathrm{pot}}\right)$ from net available energy. The model was extended to produce estimates of crop biomass production (Bastiaanssen and Ali 2003), so that crop yield and crop water productivity can be obtained on a pixel by pixel basis. Field measurements of $\mathrm{ET}_{\mathrm{act}}$ over natural vegetation surfaces and irrigated mango plantations in Brazil showed recently that the annual $\mathrm{ET}_{\text {act }}$ values of SEBAL deviates respectively $4.4 \%$ and $0.5 \%$ from the eddy correlation measurements (Teixeira et al. 2009). Publications on the accuracy of crop yield estimates are less common. Zwart and Bastiaanssen (2007) showed that reported wheat yields in Yaqui irrigation district Mexico were on average $10 \%$ lower than remote sensing estimated yields. With the development of GPS systems on harvesters, it will be easier to validate remotely sensed maps of crop yield in the near future. Moran and Jackson (1991), Kustas and Norman (1996), Courault et al. (2005), Kalma et al. (2008) and Verstraeten et al. (2008) have reviewed the role of remote sensing algorithms for estimating $\mathrm{ET}_{\mathrm{act}}$. The applicability of a satellite-based energy balance for mapping evapotranspiration is assessed by Allen et al. (2005, 2007). The usefulness of remote sensing data to provide spatial information on water resources is also demonstrated by Chowdary et al. (2008) and Casa et al. (2008). The latter applied a spatially distributed simple water balance model, which allows the estimation of temporal and spatial variation of crop water requirements.

Spatial variations of rainfall can also be estimated from satellite measurements. The accuracy of estimating rainfall from remote sensing techniques varies with the method applied and the level of calibration. The Tropical Rainfall Measurement Mission (TRMM) satellite rainfall model, available at three-hourly intervals, has accuracies between $70 \%$ and $99 \%$ (Huffman et al. 2007). The accuracy of rainfall radar technologies were recently tested by Schuurmans et al. (2007). Barret (1988), Barrett and Beaumont (1994), Petty (1995), Petty and Krajewski (1996), Kummerow et al. (1996), Smith et al. (1998), Kidd (2001) and Huffman et al. (2007) provide a complete background on the retrieval of rainfall from satellites.

Unlike conventional bases for analyzing $\mathrm{ET}_{\mathrm{act}}$ and related processes, remote sensing data is not point specific. The data can be assembled relatively quickly, based on uniform analytical procedures that have been internationally tested.

The source for agricultural water is both of rainfall and applied irrigation water. A fraction of the applied water is consumed beneficially as crop transpiration, and a fraction is consumed non-beneficially as evaporation or through transpiration of 
weeds (Perry 2007). Remote sensing estimates the total consumed fraction ET $_{\text {act }}$ and recent progress has been made to separate ET into evaporation E and transpiration $\mathrm{T}$, using the biomass production as a guideline (unpublished model from WaterWatch). Of the non-consumed fraction, some will return to drains and rivers as runoff or to an aquifer as recharge that can be exploited (the recoverable fraction). The rest goes to saline sinks, contaminated groundwater or deep aquifers not capable of economic exploitation (the non-recoverable fraction).

Agricultural production per unit of water is gradually becoming an accepted framework for management of scarce river basin water resources (e.g. Kijne et al. 2003; Molden et al. 2007). The bio-physical Crop Water Productivity CWP $\left(\mathrm{kg} \mathrm{m}^{-3}\right)$ is calculated by dividing beneficial biomass by water consumed (Eq. 1). Here, the Economic Water Productivity EWP $\left(\$ \mathrm{~m}^{-3}\right)$ is calculated by multiplying beneficial biomass by the market price, and deducting financial production costs of all inputs (except water), all divided by water consumed (Eq. 2). In case of a negative EWP, the financial costs of production exceed the gross production value (benefits).

$$
\begin{gathered}
\mathrm{CWP}_{i}=\mathrm{Y}_{i} / \mathrm{ET}_{\mathrm{act} i} \\
\mathrm{EWP}_{i}=\left(\mathrm{P}_{i}^{*} \mathrm{Y}_{i}-\mathrm{B}_{i}^{*} \mathrm{Y}_{i}-\mathrm{C}_{i}\right) / \mathrm{ET}_{\mathrm{act} i}
\end{gathered}
$$

With
$\mathrm{Y}_{i} \quad$ Beneficial biomass or yield of crop $i\left(\mathrm{~kg} \mathrm{ha}^{-1}\right)$;
$\mathrm{P}_{i} \quad$ Market price received for crop $i\left(\$ \mathrm{~kg}^{-1}\right)$;
$\mathrm{B}_{i}, \quad$ Variable financial production cost of crop $i\left(\$ \mathrm{~kg}^{-1}\right)$;
$\mathrm{C}_{i}, \quad$ Fixed financial production cost of $\operatorname{crop} i\left(\$ \mathrm{ha}^{-1}\right)$.

This approach, which is known as the residual method (Young 2005), relies on the fact that the value to a producer from producing a good is exhausted by the summation of the values of the inputs required to produce it. If the value of one input is unknown, it can be estimated by rearranging terms so that the unknown value is a function of the price by quantity of the output, less the prices by quantities of all known inputs, all divided by the quantity of the unknown input. This is the value of water or the net return to water. Some earlier examples of gross return to water using crop yield, market prices and total crop water consumption are given by Droogers et al. (2003) and Soppe et al. (2006).

One basis for arguing for transfers of water among categories of uses-sectors, crops, areas, and over time-to meet socio-political objectives will be considerably strengthened if the CWP and EWP in existing and alternative uses is known. This helps decision-makers to evaluate trade-offs between alternative water policies and courses of social actions that change water use and the multiple services it provides.

The aim of this paper is to show that this method provides indicators to assist decision making in integrated water management, by applying the method to the Inkomati Basin in the eastern part of South Africa. South Africa's National Water Act (NWA, Act 36 of 1998) explicitly adopts Equity, Sustainability and Efficiency as the principles for water management.

According to Dye and Versfeld (2007) the most fundamental shift in the way water in the country is viewed has been to democratise the ownership of water, now seen as a public good which can no longer be owned. All water users are required to register 
and licence their use of water, to pay for that water, including river or groundwater abstracted at their own expense and, in the case of plantation forestry, to pay for the reduction in streamflow which is considered to result from the forestry activity. Whilst ownership rights have been revoked, lawful users in 1998 have been allowed to register that use and these volumes have been allocated to these users. Once these volumes claimed have been verified as genuine use, such users may receive a licence. Any new user of water since 1998 is obliged to apply for a water use licence, which will only be granted if the resource is considered adequate to meet current and projected demands. The only rights to water which now pertain are the right to Basic Human Needs, and the rights of the Ecological Reserve. The Ecological Reserve is the amount of water required for safeguarding and sustaining healthy stream and river ecosystems. The national Department of Water Affairs (DWA) neatly captured the spirit of the NWA in the slogan "Some, for all, forever".

In the National Water Act there are currently 11 defined water uses. Forestry is declared as a stream flow reducing activity, while rainfed sugarcane is for instance not defined as a water use although it is known to use water.

In Section 2 spatial rainfall surplus patterns (rainfall minus $\mathrm{ET}_{\mathrm{act}}$ ) are analyzedwhich provides data essential for design and monitoring of advanced flexible water allocation policies - as well as temporal rainfall surplus patterns - which can be used to relate land use classes to streamflow patterns. Analyses of water stress and biomass production can be used to estimate crop yield reduction before harvesting and the implications for market prices. In Section 3 the spatial patterns of formally allocated water rights and actual water consumption are compared, indicating the extent to which legal entitlements are met and enforced. It will also be shown that the method can be used as a compliance tool, to trace farms that consume more irrigation water than formally allocated. In Section 4 procedures for assessing the cost-effectiveness of various ways to reduce agricultural water consumption are presented.

\section{Spatial and Temporal Variability in the Rainfall Surplus and Water Stress}

The period analyzed is the year: July 2004-June 2005. The net rainfall during that period-which is based on TRMM satellite data-was $563 \mathrm{~mm}$, which is approximately $60 \mathrm{~mm}$ less than the 20-year average figure of $622 \mathrm{~mm}$ based on the climate grids produced by the Climate and Research Unit of the University of East-Anglia. Estimated $\mathrm{ET}_{\text {act }}$ for the year ${ }^{1}$ was $694 \mathrm{~mm}$, indicating that overall the basin consumed more water than was replenished by rainfall (presumably from groundwater withdrawals or reductions in soil moisture. This does not reveal anything about the spatial or temporal variability of the consumption/supply balance.

\subsection{Spatial Variability in the Rainfall Surplus Based on Annual Rainfall and $\mathrm{ET}_{\text {act }}$ per Pixel}

On a spatial scale, rainfall surplus (rainfall minus $\mathrm{ET}_{\mathrm{act}}$ ) per $250 \mathrm{~m}$ pixel shows that in the Inkomati catchment (Fig. 1), the western upper parts are net water producing

\footnotetext{
${ }^{1}$ SEBAL is used to estimate the actual evapotranspiration $\left(\mathrm{ET}_{\text {act }}\right)$.
} 
Fig. 1 Net water producing areas (shown in blue) and net water consuming areas (shown in $r e d$ ) on a per-pixel basis in the Inkomati catchment (July 2004-June 2005)

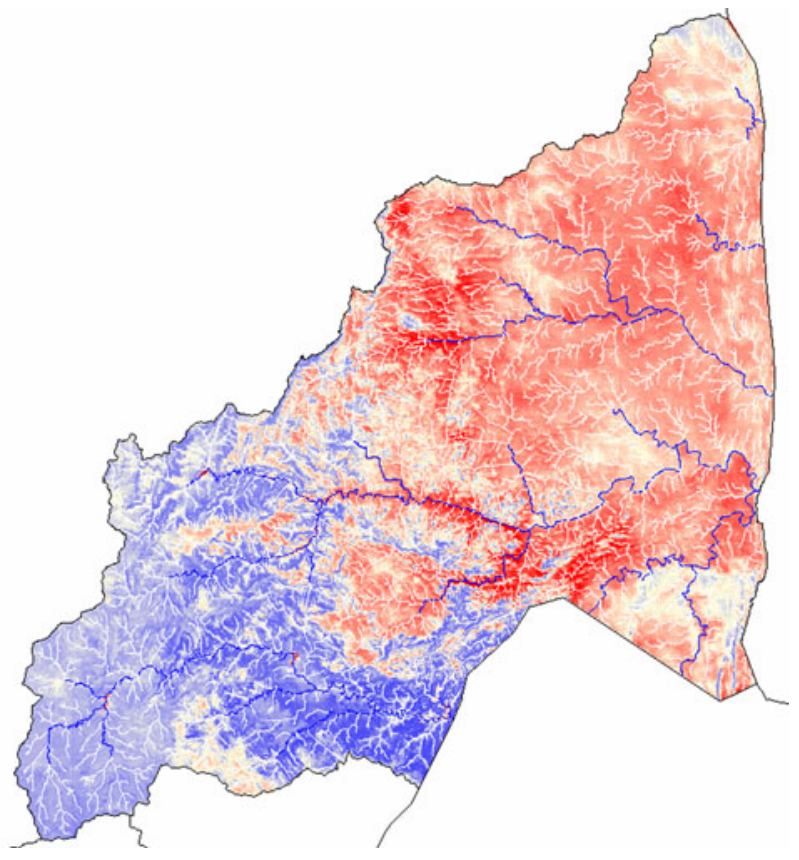

areas (shown in blue), while the eastern lower plains are net water consuming areas (shown in red). These types of spatial rainfall surplus estimates were published earlier for Sri Lanka by Bastiaanssen and Chandrapala (2003) and for Nepal by Shilpaker et al. (2009). This provides data essential for proper water monitoring and for design and monitoring of advanced flexible water allocation policies, such as tradable water rights. The potential for transfers of water can be identified from Fig. 1, but first we have to get the allocation system functioning well (i.e. basics right).

The method also allows estimation of $\mathrm{ET}_{\text {act }}$ by land use class. Table 1 shows water consumption by land use class in the Inkomti catchment, sorted by $\mathrm{ET}_{\mathrm{act}}$ in millimeter. This is useful for estimating the likely impact of changes in land use. From the table, it can be seen that although orchards, sugar cane and cash crops have the highest $\mathrm{ET}_{\mathrm{act}}$, they only consume $6 \%$ of the total volume of water consumed since the area they cover within the Inkomati catchment is relatively small (4\%). Pine and eucalyptus plantations have both a lower $\mathrm{ET}_{\text {act }}$, but use in total about $12 \%$ of the total volume of water consumed as they cover $11.5 \%$ of the area. It is also interesting to note that Kruger Park is responsible for more than $25 \%$ of the water consumed in the Inkomati catchment while accounting for less than $22 \%$ of the area-the park is a slightly above average consumer of water.

\subsection{Temporal Variability in the Rainfall Surplus Based on Monthly \\ Rainfall and $\mathrm{ET}_{\text {act }}$ per Pixel}

Note that the rainfall and $\mathrm{ET}_{\mathrm{act}}$ data presented reflect annual average values: seasonal effects are excluded. The total annual $\mathrm{ET}_{\mathrm{act}}$ of $694 \mathrm{~mm}$ can be broken down into monthly values (see Fig. 2). When combined with monthly TRMM-based rainfall 
Table $1 \mathrm{ET}_{\text {act }}$ per land use class in Inkomati catchment

\begin{tabular}{|c|c|c|c|c|c|}
\hline Land use class & $\begin{array}{l}\mathrm{ET}_{\mathrm{act}} \\
(\mathrm{mm})\end{array}$ & $\begin{array}{l}\text { Area } \\
\text { (ha) }\end{array}$ & $\begin{array}{l}\mathrm{ET}_{\text {act }} \\
\left(\mathrm{km}^{3}\right)\end{array}$ & $\begin{array}{l}\text { Percent } \\
\text { area }\end{array}$ & $\begin{array}{l}\text { Percent } \\
\text { volume }\end{array}$ \\
\hline Orchards & 1,103 & 31,492 & 0.35 & 1.1 & 1.7 \\
\hline Sugar cane & 1,067 & 62,151 & 0.66 & 2.2 & 3.3 \\
\hline $\begin{array}{l}\text { Non-pivot irrigated- } \\
\text { emerging farmer } \\
\text { cash crops }\end{array}$ & 1,029 & 1,927 & 0.02 & 0.1 & 0.1 \\
\hline $\begin{array}{l}\text { Non-pivot irrigated- } \\
\text { annual cash crops }\end{array}$ & 968 & 18,453 & 0.18 & 0.6 & 0.9 \\
\hline Water $^{\mathrm{a}}$ & 899 & 10,412 & 0.09 & 0.4 & 0.5 \\
\hline Plantation eucalypt & 841 & 100,146 & 0.84 & 3.5 & 4.2 \\
\hline Kruger Park & 831 & 613,884 & 5.10 & 21.4 & 25.6 \\
\hline $\begin{array}{l}\text { Dryland cultivation- } \\
\text { subsistence }\end{array}$ & 749 & 62,181 & 0.47 & 2.2 & 2.3 \\
\hline Urban & 738 & 68,486 & 0.51 & 2.4 & 2.5 \\
\hline Other & 678 & 3,922 & 0.03 & 0.1 & 0.1 \\
\hline Plantation pine & 662 & 230,549 & 1.53 & 8.0 & 7.7 \\
\hline Rural scattered & 656 & 21,194 & 0.14 & 0.7 & 0.7 \\
\hline Background & 621 & $1,559,150$ & 9.68 & 54.3 & 48.5 \\
\hline Plantation clear felled & 582 & 19,964 & 0.12 & 0.7 & 0.6 \\
\hline $\begin{array}{l}\text { Non-pivot irrigated- } \\
\text { grain crops }\end{array}$ & 548 & 2,555 & 0.01 & 0.1 & 0.1 \\
\hline Plantation wattle & 428 & 1,193 & 0.01 & 0.0 & 0.0 \\
\hline $\begin{array}{l}\text { Dryland cultivation- } \\
\text { commercial }\end{array}$ & 345 & 61,159 & 0.21 & 2.1 & 1.1 \\
\hline $\begin{array}{l}\text { Pivot irrigation- } \\
\text { grain crop }\end{array}$ & 344 & 2,174 & 0.01 & 0.1 & 0.0 \\
\hline $\begin{array}{l}\text { Pivot irrigation- } \\
\text { fallow }\end{array}$ & 339 & 1,294 & 0.00 & 0.0 & 0.0 \\
\hline Total & & $2,872,000$ & 20.0 & 100 & 100 \\
\hline
\end{tabular}

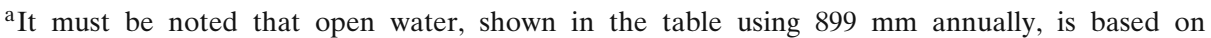
classifications of natural and man made water. Since many of the reservoirs change size during the year (they become smaller at the end of the dry season) but the classified pixels remain the same, the actual evaporation of water surfaces is likely higher. The value shown in the table is an average of water and dried reservoirs

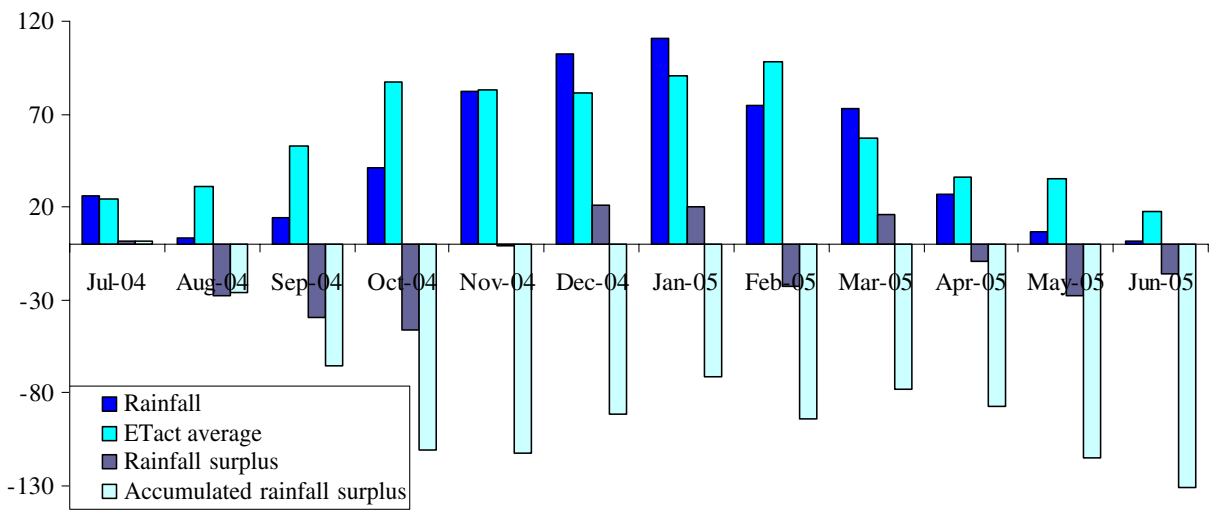

Fig. 2 Monthly rainfall, average $\mathrm{ET}_{\text {act }}$ and rainfall surplus $(\mathrm{mm})$ in the Inkomati catchment 


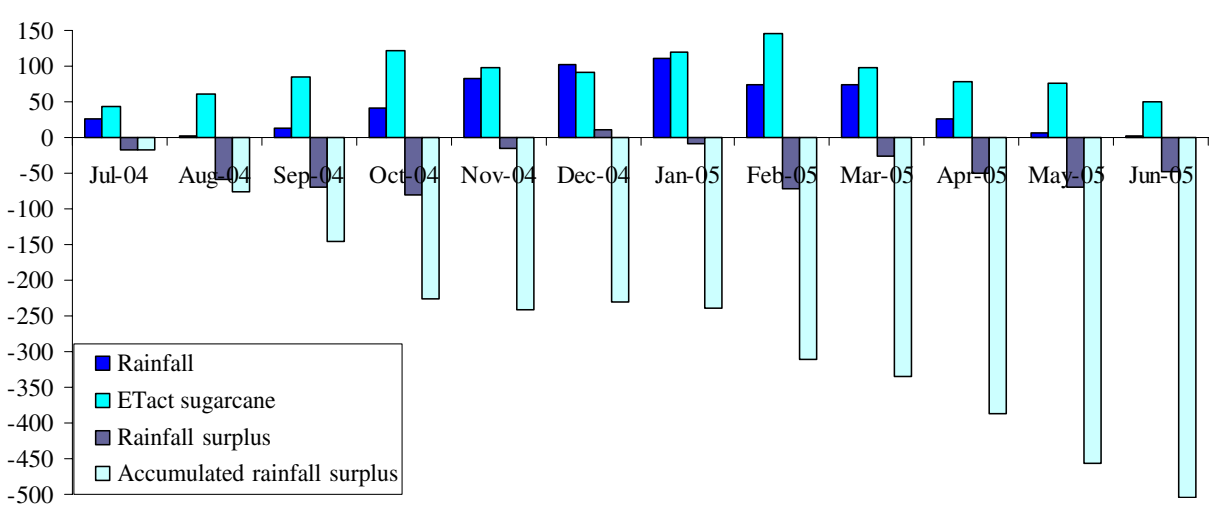

Fig. 3 Monthly rainfall, $\mathrm{ET}_{\text {act }}$ and rainfall surplus $(\mathrm{mm})$ for sugar cane in the Inkomati catchment

measurements, monthly rainfall surplus can be calculated. The sign and magnitude of the rainfall surplus indicates the impact of land use types either as net producers of water, when local consumption is less than local rainfall, or net consumers of water.

Overlaying rainfall minus $\mathrm{ET}_{\text {act }}$ with detailed land use information, individual crops can be extracted and analyzed. Figure 3, based on a total of 328,850 pixels (of $30 \times 30 \mathrm{~m}$ ) shows that sugarcane consumes more water than is supplied by rainfall in almost every month (with a total annual $\mathrm{ET}_{\text {act }}$ of $1,067 \mathrm{~mm}$ ) and consequently requires irrigation throughout the year. The contribution to $\mathrm{ET}_{\mathrm{act}}$ from i rainfall can be estimated from the ET of a neighbouring rainfed pixel. The ET from irrigation must originate from groundwater in the absence of surface water and is a good indicator of net groundwater consumption in case no records are available (Ahmad et al. 2005; Bastiaanssen and Hellegers 2007).

The distribution $\mathrm{ET}_{\mathrm{act}}$ each month can also be analyzed as a histogram (see Fig. 4). March 2005 shows interesting results. This is a period that cane is harvested and burned, and the histogram shows a much larger spread of values than in other months, because of different harvest and burn times for different fields. Some fields still have high values of $\mathrm{ET}_{\text {act }}$, since they are still growing, while other fields have low $\mathrm{ET}_{\mathrm{act}}$ as a result of harvest or burning of the cane.

\subsection{Spatial and Temporal Water Stress Based on $\mathrm{ET}_{\text {pot }}$ and $\mathrm{ET}_{\text {act }}$ per Pixel}

Water stress occurs when actual evapotranspiration $\mathrm{ET}_{\mathrm{act}}{ }^{2}$ is lower than potential evapotranspiration $\mathrm{ET}_{\text {pot }},{ }^{3}$ because the available water is limited. Spatial water stress

\footnotetext{
${ }^{2} E T_{\text {act }}$ is affected by soil moisture conditions, vegetation development and meteorological conditions.

${ }^{3} E T_{\text {pot }}$ is the evapotranspiration from a land surface whenthe crop is fully watered.
} 

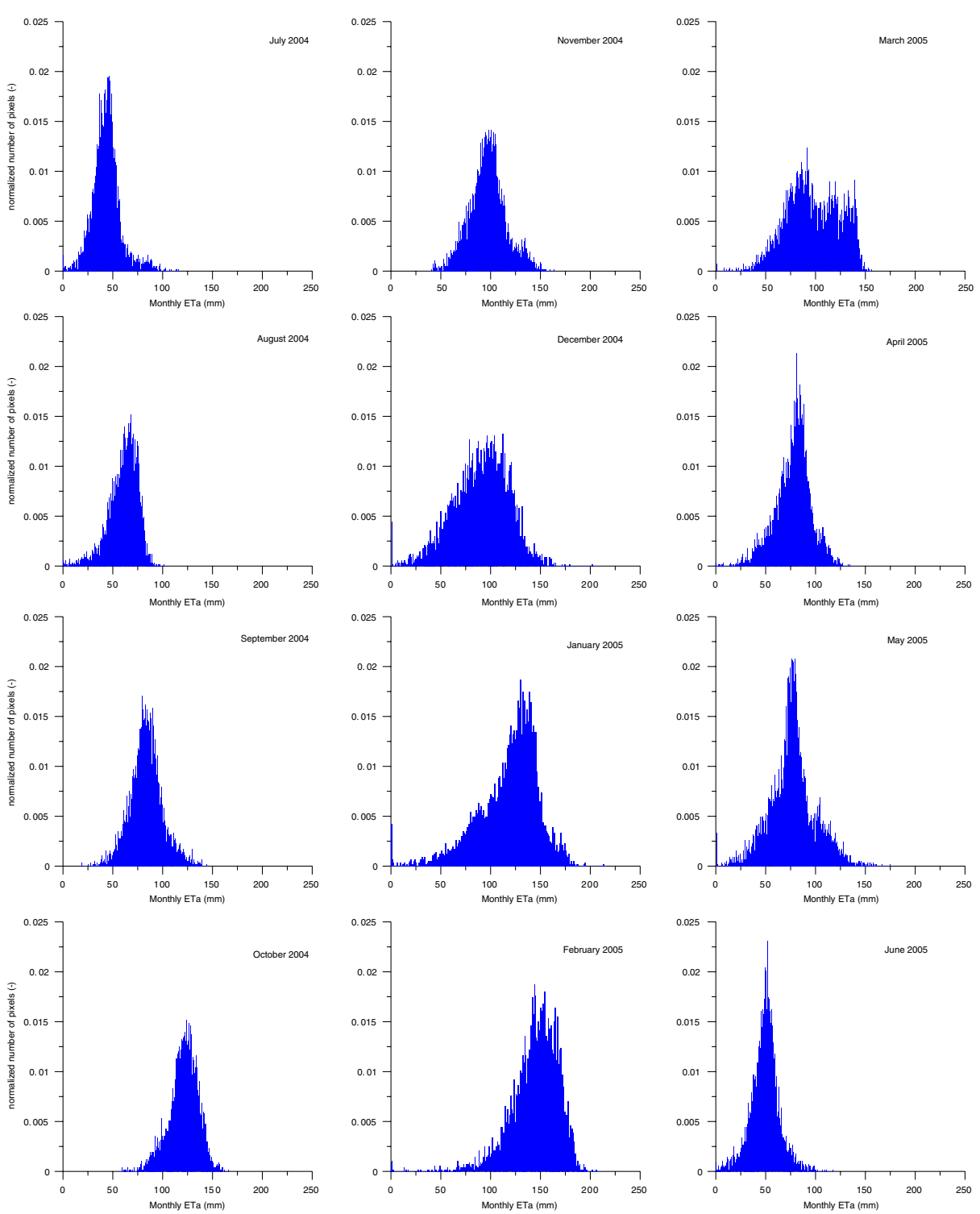

Fig. 4 Variability in monthly $\mathrm{ET}_{\text {act }}$ for sugar cane in the Inkomati catchment

maps such areas. Figure 5 shows that the forested area in the center have the highest water stress. The map shows that water stress is least severe in the irrigated areas in the lower part of the catchment, moderately stresses in the upper, rainfed catchment, and most stressed in the central catchment.

The relationship between water stress, yield, irrigation, and water productivity is complex. The basic relationship between biomass and transpiration is linear for a crop that is not otherwise constrained (by nutrient deficiency, pest attack or other constraints) (Steduto et al. 2007). However, several factors complicate this linear 
Fig. 5 Annual water stress $\mathrm{ET}_{\text {def }}$ (more reddish is more sever stress) on a per-pixel basis in the Inkomati catchment (June 2004-July 2005)

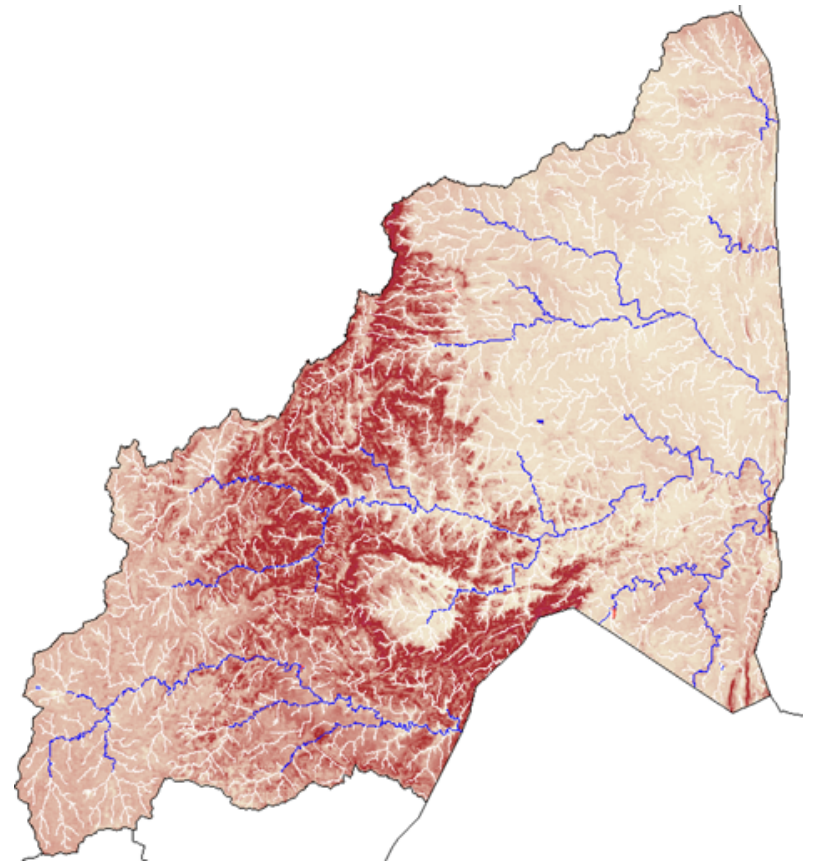

simplicity: first, deliberate water stressing during the vegetative stage for some field crops has only a small effect on grain yield so that the productivity of water can be enhanced. ${ }^{4}$ Further, stressing at certain times in the season can induce a better rooting system so that more effective use of residual soil moisture is induced-so that the productivity of irrigation water increases because total production reflects consumption of both irrigation and residual moisture. These scenarios, under non-limiting conditions in respect of other inputs, do not deviate substantially from the fundamental linear relationship between crop water consumption and yield (Perry et al. 2009).

More significant variations in CWP result from variations in crop husbandry: seed selection, planting density, land preparation, fertilization, and pesticide use all contribute to determining the potential yield a crop can achieve if water is adequate. The linear relationship alluded to above is the production frontier-and many producers, for good reasons, or just by chance-will fall short of that frontier. Figure 6, which is based on estimates of $\mathrm{ET}_{\text {act }}$ and yield for over 300,000 sugar cane pixels (236,595 pixels for commercial and 92,255 pixels for emerging farming), shows that water maximum yield is achieved at about $1,190 \mathrm{~mm}$. It also shows that many farmers are (far) below the production frontier. Mapping of $\mathrm{ET}_{\text {act }}$ against yield allows identification of low and high productivity areas for further investigation.

Variations in water productivity result from a number of factors: management, random events that cannot be controlled, and the natural productivity of the farm resources. Poor water management (excessive deliveries cause an increase in non-productive evaporation from wet soil, or inhibit growth due to waterlogging;

\footnotetext{
${ }^{4}$ Some specialist crops_-such as grapes_-benefit positively from stress in terms of sugar content and fruit quality, but are not of importance in this analysis.
} 


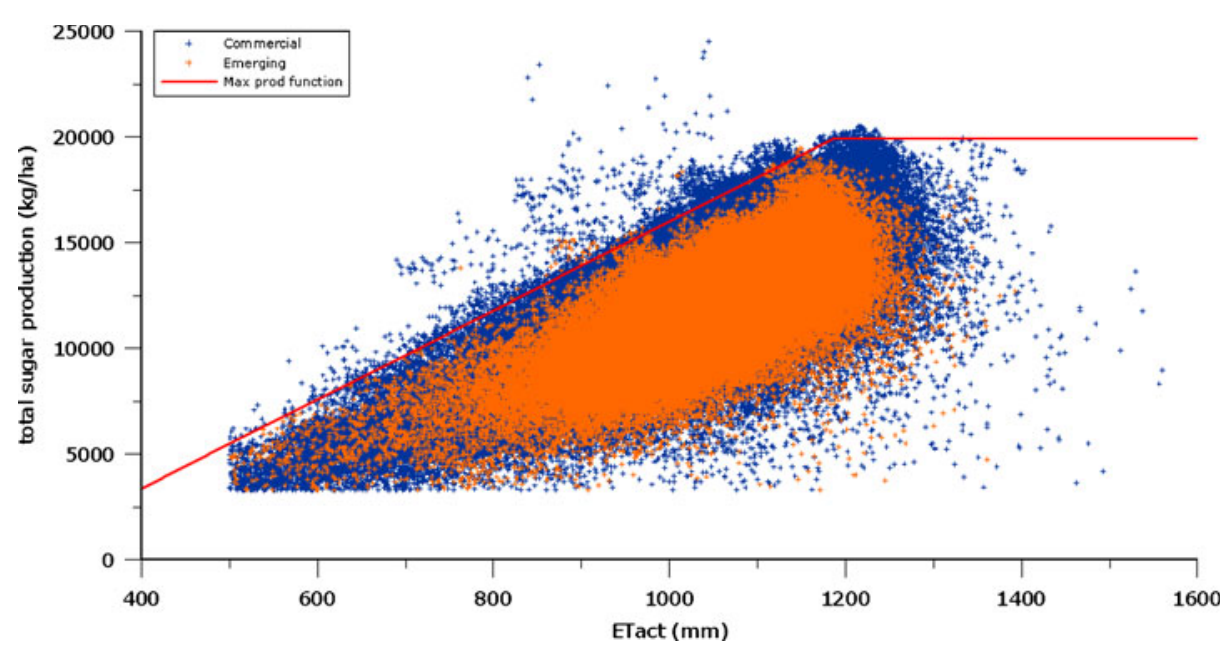

Fig. 6 Sugar production per pixel as a function of actual water consumption for commercial (blue cloud) and emerging farming (red cloud). Water consumption below $500 \mathrm{~mm}$ and sugar production below $3,500 \mathrm{~kg} / \mathrm{ha}$ are not taken into consideration. Source: Hellegers et al. (2009)

prolonged deficits, especially at critical growth stages) limit potential yield. Similarly, seed selection and seeding rates, provision of nutrients and pest protection all affect potential yield and water productivity. Severe droughts, storms, or pest attacks will randomly affect productivity, while poor soils, salinity, or high water tables, will continuously limit potential. Consideration of these various factors in relation to the estimates of water productivity indicate that additional analysis is needed to establish reasons for good or bad productivity levels: time series should show up random impacts, while ground investigation, or relating productivity to mapped characteristics of soils, water tables, etc may further explain continuous poor performance.

\section{Detecting Areas with Apparent Excess Water Use}

In this section the fraction of the total farm size to which water rights have been allocated is used as an indicator of the pattern of authorized access to water. Further, the volume of formally allocated water will be compared to actual consumed water on commercial farms in two regions (Lomati and Komati) to trace trade of water rights or detect unauthorized irrigation water use.

Data on farm and plot boundaries and formally allocated water rights per farm were provided as GIS layers by the Department of Water Affairs and Forestry (DWAF). Water rights (a) are based on a fraction of the farm, (b) are a specific volume per hectare for that fraction, but (c) may be used on a greater or lesser area than is authorized providing the abstraction volume implied by a and $\mathrm{b}$ is adhered to.

Figure 7 shows that the fraction of the total farm size to which water rights have been allocated is larger closer to the river; probably due to easier access and consequently higher historical usage. The allocated fraction varies considerably. The figure also shows that farms in Lomati have a larger allocated fraction than farms in Komati. The formally allocated volume per hectare is lower in Lomati $\left(8,500 \mathrm{~m}^{3} \mathrm{ha}^{-1}\right.$ year $\left.^{-1}\right)$ than in $\operatorname{Komati}\left(9,950 \mathrm{~m}^{3} \mathrm{ha}^{-1}\right.$ year $\left.^{-1}\right)$. 


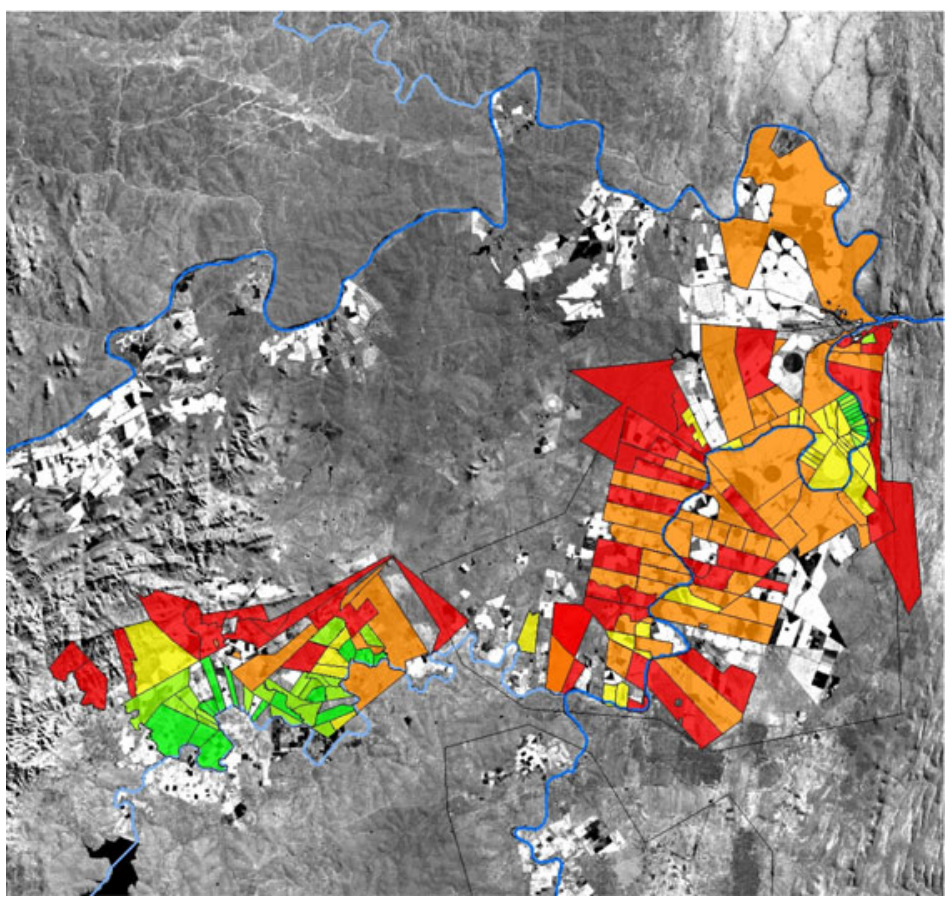

Lomati \& Komati allocatie_indicator

$0.00-0.20$

$0.21-0.40$

$0.41-0.60$

$0.61-0.80$

$0.81-1.00$

Fig. 7 Fraction of total farm size to which water rights have been allocated for commercial farming in Lomati (on the left) and Komati (on the right)

Figure 8 shows that average water consumption per plot is generally higher in Komati than in Lomati, which can be related to the intensity of sugarcane. Comparison with Fig. 7 shows that those farms with the highest allocated fraction are not necessarily the largest actual water consumers per plot. This may partly be due to the difference in the allocated volume per hectare in Lomati and Komati-the volume of formally allocated water is compared to the actual consumed water.

The volume of formally allocated water is compared to $\mathrm{ET}_{\text {act }}$ in the left part of Fig. 9 and to $\mathrm{ET}_{\text {act }}$ minus rainfall (which is uniformly assumed to be $550 \mathrm{~mm}$ ) in the right part. Points on the 45 degree line correspond to the (unlikely) situation where consumed (irrigation) water is equal to formally allocated (abstracted) water. Points below the line can be explained by two factors: either the farmer did not apply his full entitlement of water, or a significant proportion of the water applied was not converted into $\mathrm{ET}_{\text {act }}$ but instead went to drainage or deep percolation. Trading of water rights would also be an explanation. Points above the 45 degree line indicate farms where consumed irrigation water exceeds the formally allocated volume. Excessive use suggests, if no water trading is taking place, that unauthorized water consumption could be the case. In Komati there is more excessive use than in Lomati. About $85 \%$ of the farms $(n=149)$ in Komati consumes more irrigation water than they are entitled to. About half of the farms consume more than twice the allocated volume and one-third uses even more than three times the allocated volume. In Lomati about $35 \%$ of the farms $(n=88)$ consume more than they are entitled to. A quarter is consuming more than twice the allocated volume and 


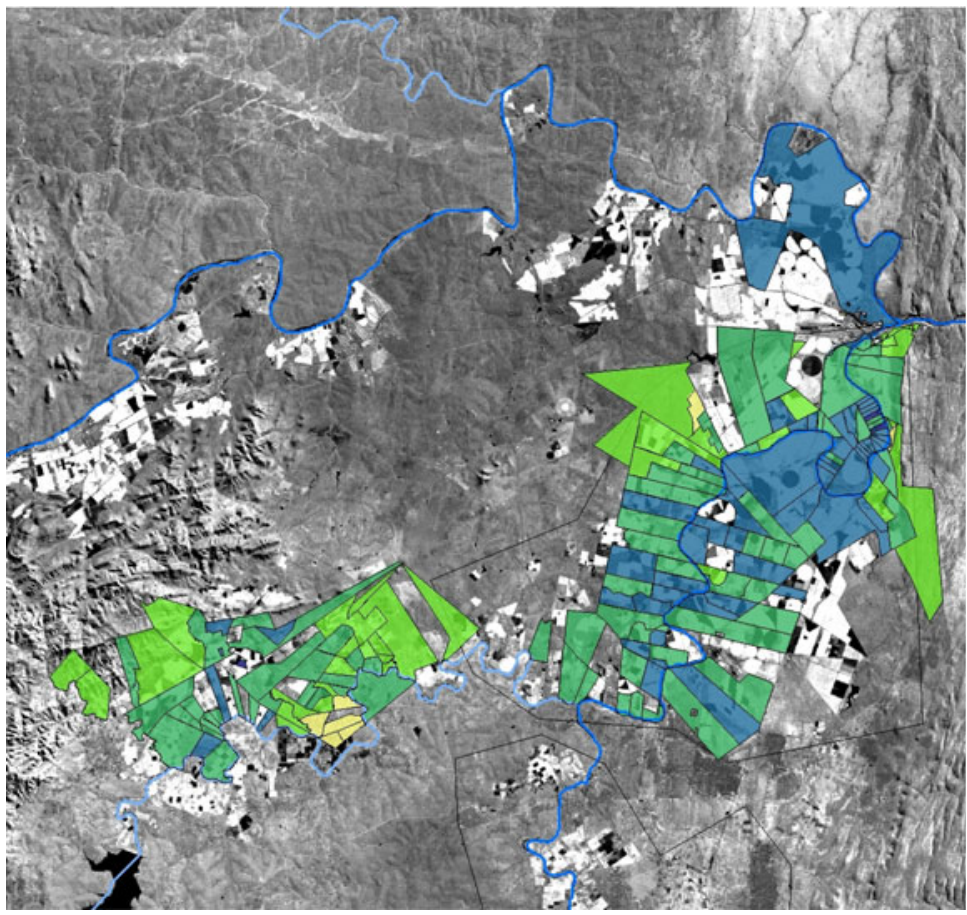

\section{Avg ETa per plot}

$\mathrm{mm}$

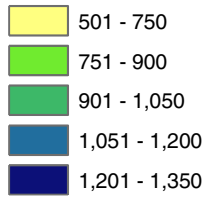

Fig. $8 \mathrm{ET}_{\text {act }}$ per plot for commercial farming in Lomati (left part) and Komati (right part)

$15 \%$ consumes more than three times the allocated volume. Obviously only a small part of such excessive consumption can be explained by trading, because total use substantially exceeds total authorised use.
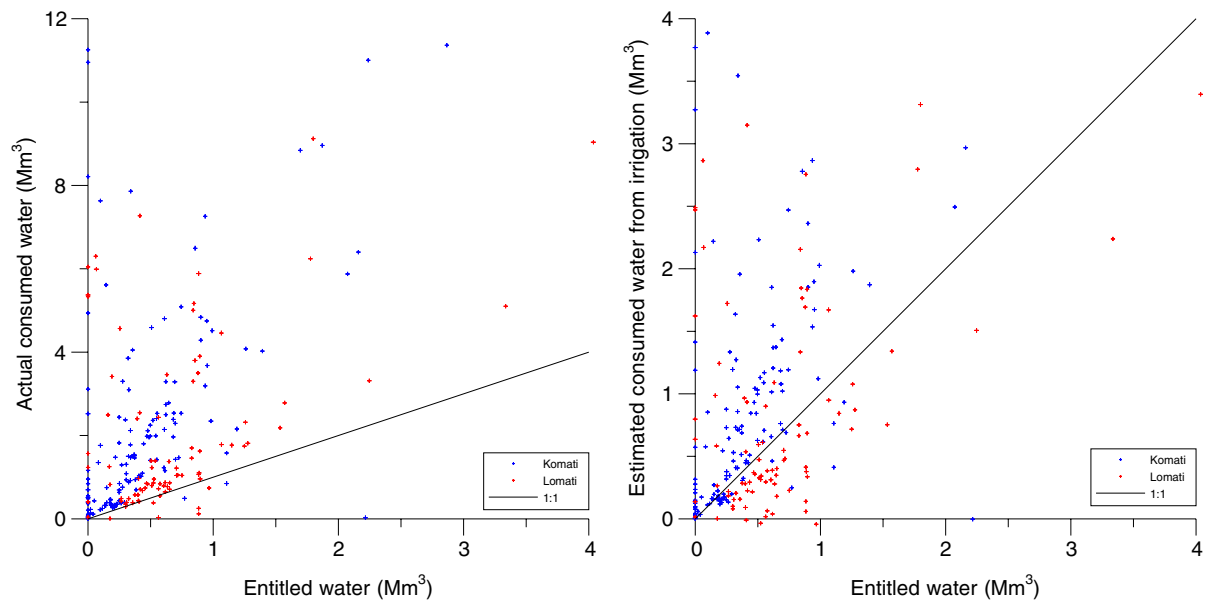

Fig. 9 Comparison of volume entitlement and actual consumed water (left part) and comparison of volume entitlement and consumed irrigation water assuming $550 \mathrm{~mm}$ of rainfall (right part) at commercial farms in Komati and Lomati 


\section{Cost-Effective Ways of Reducing Agricultural Consumption}

According to the South-African Water Act, water has to be reserved for Basic Human Needs and for the Ecological Reserve. It is, however, hard to quantify socioeconomic gains from achieving such socio-political objectives (see Hellegers 2006 and Hellegers and Perry 2006). It is therefore especially important to inform policy makers of the costs of achieving such objectives. Cost-effectiveness curves-based on the opportunity costs (foregone benefits to agriculture) of diverting water away from agriculture-provide an indicator to show policy makers the cost of water diversions.

For the purposes of the analysis presented below, the caveats set out in Section 2 regarding the various causes for apparent poor production, and the need to collect productivity information over time, are ignored. Correction and adjustment of the data over time will lead to a revised distribution of performance, to which the approaches defined below to assessing alternative means of reducing water consumption can be applied.

Agricultural water consumption can be reduced in various ways. The four methods, which do not allow farmers to trade water, are described below and visually illustrated in Appendix. Each row in Appendix represents one of the four methods of reducing agricultural water consumption by $15 \%, 30 \%$ and $45 \%$.

Method 1: Agricultural areas with lowest CWP are taken out of production first. This cuts back the low-productive, left tail of the CWP histograms in Appendix.

Method 2: Agricultural areas with lowest EWP are taken out of production first. It is a reduction in economically low-performing areas-the left tail of the EWP histograms in Appendix.

Method 3: Water use is rationed to a maximum volume per hectare-a quota. This affects the largest $\mathrm{ET}_{\text {act }}$ per hectare users most. Water use that exceeds the quota can be either beneficial or non-beneficial consumption. It is assumed that first the non-beneficial consumption is reduced by means of improved management practices without biomass losses.

Method 4: Water is reduced proportionally (i.e. with an equal share of water consumed). Again it is assumed that first non-beneficial consumption is reduced, in this case by all water users. So if all farmers below the production frontier shown in Fig. 6 can reduce water use without biomass losses, agricultural water consumption can be reduced substantially with zero costs. Whether this is a realistic assumption in reality depends on the factors that determine the differences in productivity.

Figure 10 shows that method 1 and 2 have similar effects. Reducing 50\% of water consumption reduces about $45 \%$ of the biomass production and $40 \%$ of the net production value of each crop (except for bananas). The results of method 1 and 2 would be different if applied to all crops (instead of to specific crops), as under method 1 emerging sugar cane would be reduced first, while under method 2 bananas would be reduced first.

Methods 1 and 2 have different effects for bananas. This is due to the fact that for low CWP values of bananas there is no strong relationship (correlation) between the CWP and EWP. This can be explained by the high fixed production costs of bananas, which is a relatively heavy burden for low-productive users. There is a stronger 


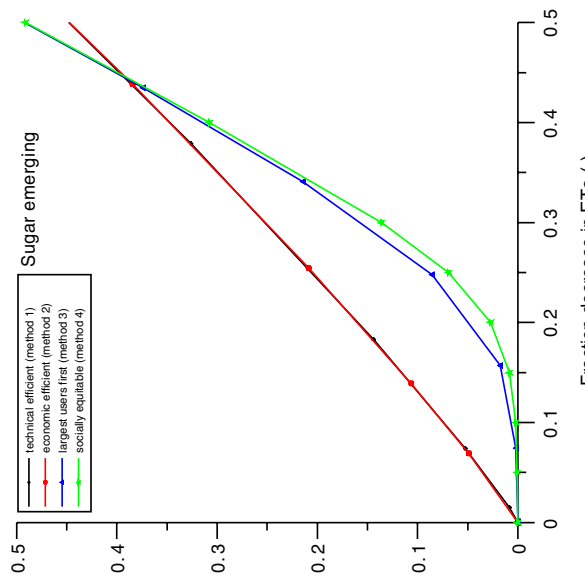

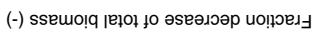

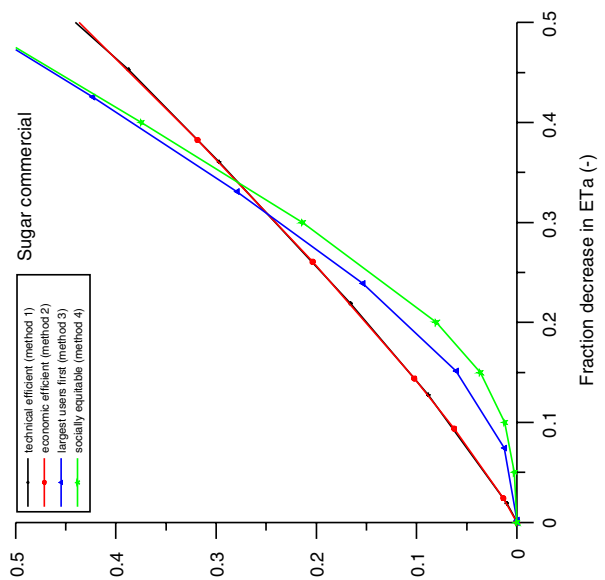

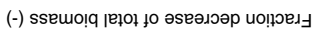

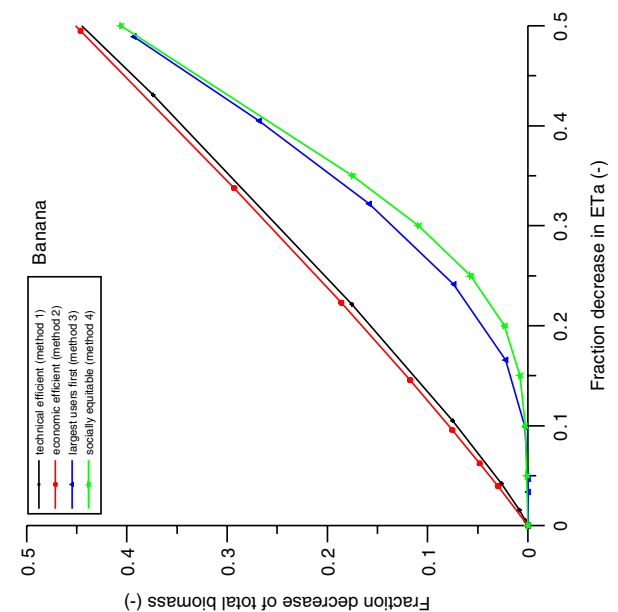

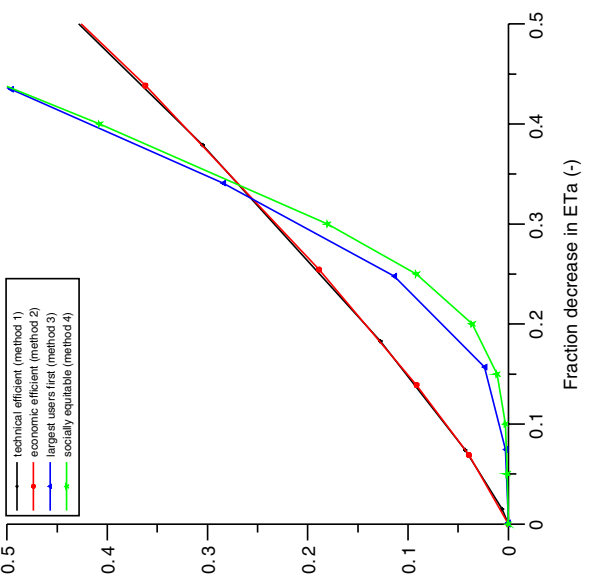

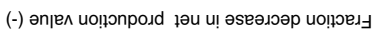

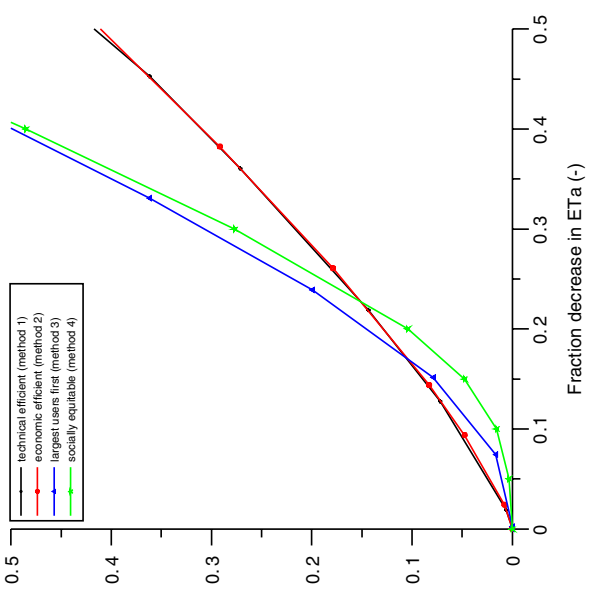

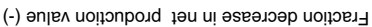

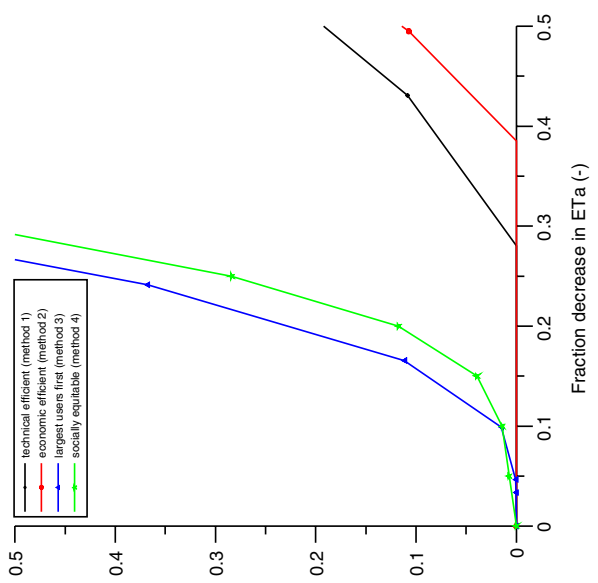

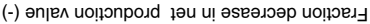


Fig. 10 Fraction decrease in total biomass (top row) and in total net production value (bottom row) as a function of the fraction decrease in actual water consumption for the four methods of reducing water consumption for bananas, commercial and emerging sugar (left to right)

relationship between the CWP and EWP for sugar cane (see Fig. 3 of Hellegers et al. 2009).

Method 4 is more cost-effective than method 3. This might be counterintuitive, but in our analysis method 4 provides all (not just the largest) water users incentives to improve water management practices. This is due to the assumption that nonbeneficial consumption can be reduced by all water users without any costs in the case of method 4, while in the case of method 3 it is assumed that non-beneficial consumption is only reduced by those that exceed the quota. The two graphs eventually converge, since under method 3 an increasing number of water users also receive this incentive. It is a convex relationship, because initially most users can meet the quota by reducing the non-beneficial consumed fraction, but eventually an increasing number of users have to reduce the beneficial consumed fraction and costs of biomass losses will increase at an increasing rate.

From this analysis it becomes clear that reducing all water use proportionally is the most cost effective way of releasing small volumes of water, as it provides incentives to all users to reduce their non-beneficial consumed fraction while maintaining their biomass production. Taking low-performing agricultural areas (with a low CWP) out of production is, however, a cheaper way of releasing larger volumes of water. For bananas the most cost-effective way of reducing water consumption is to take agricultural areas with negative EWP out of production.

\section{Conclusions}

In this paper the usefulness of remote sensing estimates of $\mathrm{ET}_{\mathrm{act}}, \mathrm{ET}_{\mathrm{pot}}$, biomass production and rainfall in combination with economic analysis has been demonstrated in the Inkomati Basin in the eastern part of South Africa. This method is widely applicable to water resource policy-making and monitoring. It shows where water is available and where it is consumed by what crops. It shows where there are surpluses, and how these relate to land use. It also provides a basis to track current consumption and potentially extend the definitions of water user to different categories of users in South Africa. While a strong Water Act is in place, implementation of the water policy envisaged remains a challenge - part of which relates to the availability of data.

Remote sensing is a useful source of important basic data-where water is being consumed, how this relates to assigned water rights, how land use affects water availability, and where water is being most and least productively used.

Finally, it has been demonstrated that the combination of remote sensing and economic analysis allows comparison of the opportunity costs of allocating water in a socially desirable way. This will strengthen the basis for arguments to transfer water between users. This approach also provides insights into the cost-effectiveness of various ways to divert water away from agriculture.

Open Access This article is distributed under the terms of the Creative Commons Attribution Noncommercial License which permits any noncommercial use, distribution, and reproduction in any medium, provided the original author(s) and source are credited. 


\section{Appendix: Different approaches of reducing water consumption}

Each row represents one of the methods of ET reduction as used in the study.

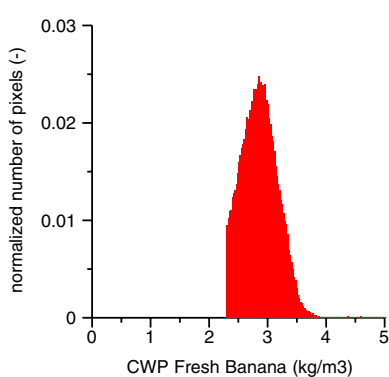

Method 1: 15\% reduction

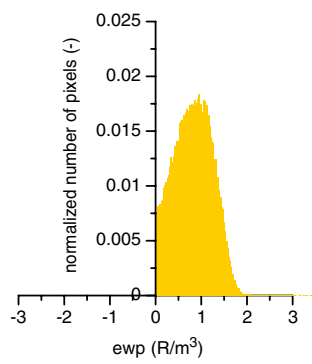

Method 2: 15\% reduction

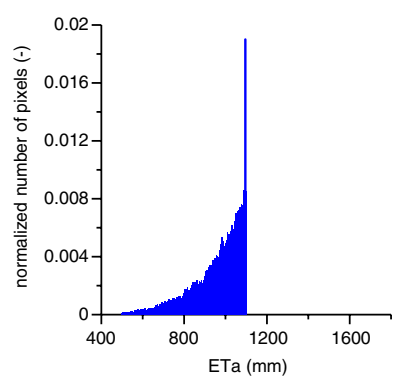

Method 3: 15\% reduction

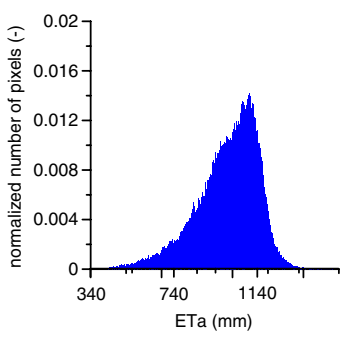

Method 4: 15\% reduction

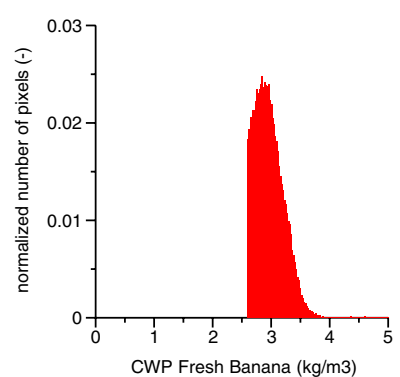

Method 1: $30 \%$ reduction

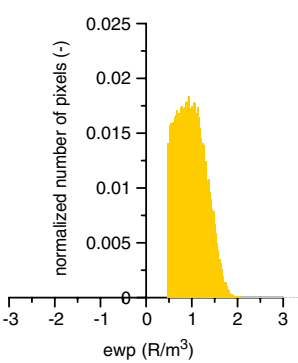

Method 2: 30\% reduction

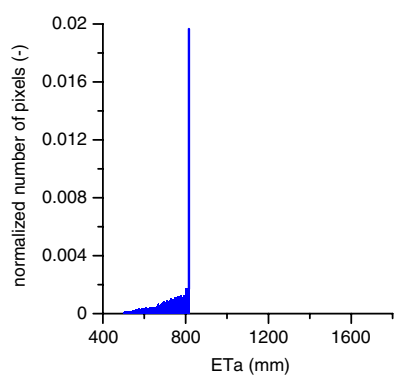

Method 3: 30\% reduction

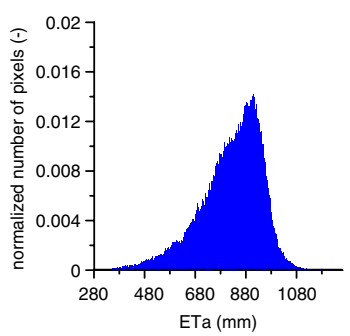

Method 4: 30\% reduction

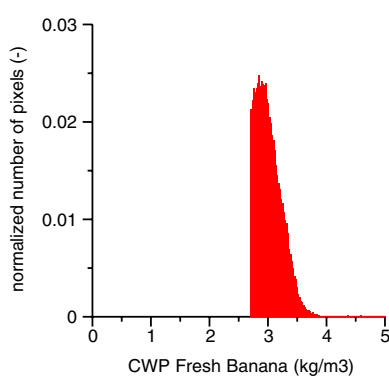

Method 1: 45\% reduction

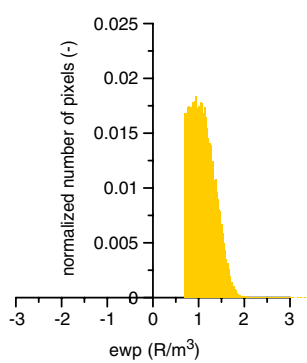

Method 2: 45\% reduction

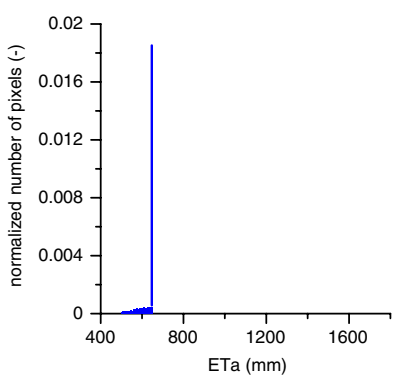

Method 3: 45\% reduction

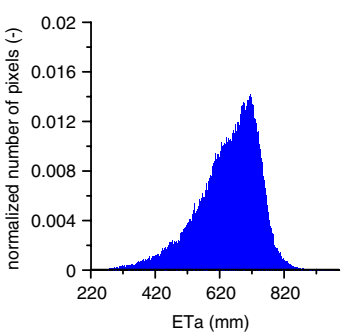

Method 4: 45\% reduction 


\section{References}

Ahmad MD, Bastiaanssen WGM, Feddes RA (2005) A new technique to estimate net groundwater use across large irrigated areas by combining remote sensing and water balance approaches, Rechna Doab, Pakistan. J Hydrogeol J 13:653-664

Allen RG, Tasumi M, Morse A, Trezza R (2005) A Landsat-based energy balance and evapotranspiration model in Western US water rights regulation and planning. Irrig Drain Syst 19:251-268

Allen RG, Tasumi M, Morse A, Trezza R, Wright JL, Bastiaanssen W, Kramber W, Lorite I, Robison CW (2007) Satellite-based energy balance for mapping evapotranspiration with internalized calibration (METRIC) — applications. ASCE J Irrig Drain Eng 133(4):395-406

Barret EC (1988) Precipitation monitoring by satellites. Remote sensing for studies of global environmental changes. ISPRA Courses, RS/88/10, Commission of European communities, Joint Research Center, Ispra Establishment, Italy

Barrett EC, Beaumont MJ (1994) Satellite rainfall monitoring: an overview. Remote Sens Rev 11: 23-48

Bastiaanssen WGM, Ali S (2003) A new crop yield forecasting model based on satellite measurements applied across the Indus Basin, Pakistan. Agric Ecosyst Environ 94(3):321-340

Bastiaanssen WGM, Chandrapala L (2003) Water balance variability across Sri Lanka for assessing agricultural and environmental water use. Agric Water Manag 58(2):171-192

Bastiaanssen WGM, Hellegers PJGJ (2007) Satellite measurements to assess and charge for groundwater abstraction. In: Dinar A, Abdel Dayem S, Agwe J (eds) The role of technology and institutions in the cost recovery of irrigation and drainage projects. Agriculture and Rural Development discussion paper 33. The World Bank, Washington

Bastiaanssen WGM, Ahmed MD, Chemin Y (2002) Satellite surveillance of evaporative depletion across the Indus Basin. Water Resour Res 38:1273-1282

Bastiaanssen WGM, Noordman EJM, Pelgrum H, Davids G, Allen RG (2005) SEBAL for spatially distributed ET under actual management and growing conditions. ASCE J Irrig Drain Eng 131:85-93

Casa R, Rossi M, Sappa G, Trotta A (2008) Assessing crop water demand by remote sensing and GIS for the Pontina Plain Central Italy. Water Resour Manag 23(9):1685-1712

Chowdary VM, Ramakrishnan D, Srivastava YK, Chandran V, Jeyaram A (2008) Integrated water resource development plan for sustainable management of Mayurakshi watershed, India using Remote Sensing and GIS. Water Resour Manag 23(8):1581-1602

Courault D, Seguin B, Olioso A (2005) Review on estimation of evapotranspiration from remote sensing data: from empirical to numerical modeling approaches. Irrig Drain Syst 19:223-249

Droogers P, Malik RS, Kroes JG, Bastiaanssen WGM, van Dam JC (2003) Future water management in Sirsa district: options to improve water productivity. In: van Dam JC, Malik RS (eds) Water productivity of irrigated crops in Sirsa district, India. WUR and CCS Haryana Agricultural University, Haryana

Dye P, Versfeld D (2007) Managing the hydrological impacts of South African plantation forests: an overview. For Ecol Manag 251:121-128

Hellegers PJGJ (2006) The role of economics in irrigation water management. Irrig Drain 55:157-163

Hellegers PJGJ, Perry CJ (2006) Can irrigation water use be guided by market forces? Theory and practice. Int J Water Resour Dev 22(1):79-86 (special issue)

Hellegers PJGJ, Soppe R, Perry CJ, Bastiaanssen WGM (2009) Combining remote sensing and economic analysis to support policy decisions that affect water productivity. Irrig Sci 27(3): $243-251$

Huffman GJ, Adler RF, Bolvin DT, Gu G, Nelkin EJ, Bowman KP, Hong Y, Stocker EF, Wolff DB (2007) The TRMM multi-satellite precipitation analysis: quasi-global, multi-year, combinedsensor precipitation estimates at fine scale. J Hydrometeorol 8:38-55

Kalma JD, McVicar TR, McCabe MF (2008) Estimating land surface evaporation: a review of methods using remotely sensed surface temperature data. Surv Geophys 29:421-469

Kidd C (2001) Satellite rainfall climatology: a review. Int J Climatol 21(9):1041-1066

Kijne JW, Barker R, Molden D (2003) Water productivity in agriculture: limits and opportunities for improvement (Comprehensive Assessment of Water Management in Agriculture Series 1). CABI, Wallingford

Kummerow C, Olson WS, Giglio L (1996) A simplified scheme for obtaining precipitation and vertical hydrometeor profiles from passive microwave sensors. IEEE Trans Geosci Remote Sens 34:1213-1232 
Kustas WP, Norman JM (1996) Use of remote sensing for evapotranspiration monitoring over land surfaces. Hydrol Sci J 41(4):495-516

Molden D, Oweis T, Steduto P, Kijne JW, Hanjra MA, Bindraban PS (2007) Pathways for increasing agricultural water productivity. In: Water for food, water for life: a comprehensive assessment of water management in agriculture, chapter 7. Earthscan. http://www.iwmi.cgiar.org/ assessment/Publications/books.htm

Moran MS, Jackson RD (1991) Assessing the spatial distribution of evapotranspiration using remotely sensed inputs. J Environ Qual 20:725-737

Perry CJ (2007) Efficient irrigation; inefficient communication; flawed recommendations. Irrig Drain 56(4):367-378

Perry CJ, Steduto P, Allen RG, Burt CM (2009) Increasing productivity in irrigated agriculture: agronomic constraints and hydrological realities. Agric Water Manag 96:1517-1524

Petty GW (1995) The status of satellite-based rainfall estimation over land. Remote Sensing Environ 51:125-137

Petty GW, Krajewski W (1996) Satellite rainfall estimation over land. Hydrol Sci J 41:433-451

Schuurmans JM, Bierkens MFP, Pebesma EJ Uijlenhoet R (2007) Automatic prediction of high resolution daily rainfall fields for multiple extents: the potential of operational radar. J Hydrometeorol 8(6):1204-1224

Shilpaker RL, Bastiaanssen WGM, Molden D (2009) Geoinformation procedures to assist water accounting: a case study of the East Rapti river basin, Nepal. Kluwer, Dordrecht (in press)

Smith DM, Kniveton DR, Barrett EC (1998) A statistical modelling approach to passive microwave rainfall retrieval. J Appl Meteorol 37(2):135-154

Soppe RWO, Hellegers PJGJ, Perry CJ, Boon D, Bastiaanssen WGM, de Wit M, Pelgrum H (2006) Combining remote sensing and economic analysis to assess water productivity: a demonstration project in the Inkomati Basin. LEI and WaterWatch Report, Wageningen

Steduto P, Hsiao TC, Fereres E (2007) On the conservative behavior of biomass water productivity. Irrig Sci 25:189-207

Teixeira AH, Bastiaanssen WGM, Ahmad MD, Bos MG (2009) Reviewing SEBAL input parameters for assessing evapotranspiration and water productivity for the Low-Middle Sao Francisco River basin, Brazil. Part A: calibration and validation. Agric For Meteorol 149(3-4):462-476. doi:10.1016/j.agrfor-met.2008.09.016

Verstraeten WW, Veroustraete F, Feyen J (2008) Assessment of evapotranspiration and soil moisture content across different scales of observation. Sensors 8(1):70-117

Young R (2005) Determining the economic value of water: concepts and methods. Resource for the Future, Washington.

Zwart SJ, Bastiaanssen WGM (2007) SEBAL for detecting spatial variation of water productivity and scope for improvement in eight irrigated wheat systems. Agric Water Manag 89:287-296 